\title{
Discussion on the Construction of Practice Teaching Base in Local Colleges and Universities: Perspective of Transformation and Upgrading of Industrial Clusters
}

\author{
Wu Zhaoshan \\ Jiaxing University, Jiaxing, Zhejiang Province, China, 314200
}

Keywords: industrial cluster; practical teaching; applied type; transformation and upgrading

\begin{abstract}
The construction of practical teaching bases is an important way for colleges and universities to cultivate high-quality applied talents. From the perspective of the transformation and upgrading of local industrial clusters, the changes in the demand for applied talents and the existing problems in the construction of practical teaching bases for local colleges and universities are discussed. The long-term mechanism for the establishment of school-industry cooperation, the improvement of the practical education management model of the base, and the design and system of standardized teaching planning are proposed. Four measures to strengthen the construction of practice teaching base in management and enhancing teachers' "Double Teachers" quality has been put forward, which will play a constructive role in the construction of practical teaching bases for local colleges and universities.
\end{abstract}

\section{Introduction}

The transformation and upgrading of industrial clusters is not only an upgrade of products and markets, but also an upgrade of talents, highlighting the important value of talents. The development of local colleges and universities needs to meet the requirements of the applied talents proposed by the transformation and upgrading of industrial clusters, and the construction of applied universities aims to cultivate high-level and high-quality applied technology talents, and will further emphasize the cultivation of students' practical application capabilities. Therefore, the practice teaching base is an important carrier for developing students' practical ability and social adaptability, and its construction and development have become particularly important. How to build a practical teaching base and adapt to the needs of local economic development has become one of the topics that local universities focus on.

\section{Demand for Applied Talents in the Context of Transformation and Upgrading of Local Industrial Clusters}

2.1 New requirements for the structure of applied talents in the context of transformation and upgrading of local industrial clusters

The new requirements for the application-type talent structure of industrial economic development are mainly application technology and scientific and technological innovation talents. The applied talents are roughly composed of three types of talents: technological innovation, applied technology, and applied skills. In different stages of economic development, the development of industrial enterprises has significant differences in the demand for different types and types of applied talents. In the stage of economic development led by extensive economic growth mode and labor-intensive mode, the industry's dependence on foreign technology is high, independent research and development capabilities are weak, and the added value of products is low. The demand for applied talents in industrial economic development is mainly based on applied skills and technology. Talent based. In the stage of economic development led by intensive economic growth mode and knowledge-intensive technology, large-scale enterprises have begun to increase investment in scientific and technological innovation, and have taken high-tech to realize 
industrial economic development. Small and medium-sized enterprises have begun to focus on technological transformation and product upgrading. Take the technological progress to realize the road of enterprise connotation development. The demand for applied talents in the industrial economic development is mainly based on application technology and scientific and technological innovation talents. Therefore, local colleges and universities should timely adjust the training strategy of applied talents according to the different stages of development of the regional economy, accurately formulate personnel training specifications and standards that meet the transformation and upgrading of industrial structure, and actively serve the regional economic transformation and development.

\subsection{New requirements for the knowledge demand of applied talents in the context of transformation and upgrading of local industrial clusters}

The new requirements for the knowledge-based talents in industrial economic development are mainly to create complex and cross-boundary knowledge systems. The "World Competitiveness Yearbook" issued by the International Institute for Management Development in Lausanne, Switzerland, clearly stated that the international competitiveness of Chinese engineering and technologists is at an intermediate level in more than 60 countries and regions in the world, and the degree of qualification of engineers is at the end of the global scale. Level [1]. At present, with the transformation and development of local economies, and on the basis of in-depth readjustment of the industrial structure, efforts have been made to promote the transformation and upgrading of regional industrial clusters, and then put forward new requirements for the applied talents' knowledge structure. At present, the establishment of some professional settings and curriculum systems in local colleges and universities is still centered on traditional industries. It has not closely linked with regional economic transformation and industrial upgrading. This has led to a mismatch between the students' knowledge, the knowledge structure formed, and the market demand. Therefore, local colleges and universities only seek breakthroughs in the timely adjustment of professionalism and the renewal of curriculum systems. They focus on the industrial construction profession, integrate into corporate building courses, break academic barriers, dismantle professional barriers, and pay attention to cross-discipline and cross-discipline cross-knowledge system construction in order to cultivate The application-oriented undergraduate talents with solid professional technology and compound knowledge system are in line with the transformation and development of the regional economy.

\section{The predicament faced by the construction of practice teaching base in local colleges and universities}

At present, local colleges and universities have reached a consensus on the key to improving the quality of talent training in local colleges and universities, highlighting the characteristics and connotation of running schools, and finally achieving the key to serving the socio-economic development. Practical and effective positive measures have been adopted to create a practical teaching base. The practice teaching base construction is in a good situation. However, under the background of the transformation and upgrading of local industrial clusters, there are still many problems in the construction of practical teaching bases for local universities, which are mainly reflected in the following aspects:

\subsection{The incomplete construction of a practical teaching base}

(1) The lack of market thinking in colleges and universities. In the process of joint construction of a practical teaching base, only relying on the "standard" of the university does not fully consider the essential characteristics of the enterprise as a market subject in pursuit of economic benefits, and enterprises cannot obtain their own benefits from it. Sometimes, it will cause the increase of manpower, material resources and production costs of the enterprise, which will dampen the enthusiasm of enterprises to participate in school practice teaching. (2) The ability of local colleges and universities to provide services to local enterprises is lacking. Talents, scientific research, and 
technological advantages of colleges and universities have not effectively translated into the actual needs of local enterprises. Enterprises lack the enthusiasm to cooperate with universities in building a practical teaching base. (3) Enterprises have insufficient understanding of social responsibility. Enterprises more regard themselves as economic entities, and neglect their social responsibilities and obligations as social subjects. Based on production safety and order, management costs, and economy in consideration of benefits and other aspects, companies undertake to cooperate with universities to build practical teaching bases to cultivate applied talents. Social responsibility awareness is not strong, and enthusiasm and initiative are not high. (4) Local governments' support for school-enterprise cooperation is insufficient, or only macro guidance and lack of specific measures have not played a role in the bond between universities and enterprises.

\subsection{The imperfect connotation construction of the practical teaching base}

In the process of building a practical teaching base, local universities have a tendency to "re-establish quantity, light quality" and "re-establish and lighten construction". The lack of connotation construction or lack of place makes most of the construction of bases in formal or useless forms. We will give full play to the carrier function of application-oriented personnel training. The main manifestations are as follows: (1) There is a shortage of "dual-qualified" teachers. Young teachers generally have high academic qualifications and strong scientific research capabilities. However, they do not have a corporate engineering background, lack of practical experience, and they have a difficult teaching task, which makes it difficult to effectively train students. The guidance has become a "bottleneck" for effective practice teaching. (2) The practical teaching program is derailed from the actual production of the enterprise, and the compatibility of the internship content with professional learning is poor. At the same time, the enterprise considers factors such as business secrets, business safety, and counseling strength. Students participating in internships often have access to non-core students. Business work, even just engaging in some simple labor, has affected the effectiveness of practical teaching. (3) Practice teaching focuses on forms, results are light, and process management is extensive. At the same time, the evaluation mechanism is not perfect, and the school's "unary" evaluation mechanism makes the evaluation results unable to accurately and objectively reflect the effect of practical teaching.

\subsection{The relatively low overall efficiency of the practical teaching base}

The multi-faceted performance brought about by the construction of practical teaching bases mainly includes three aspects: personnel training, scientific research, and social services. However, at present, the effectiveness of local colleges' practical teaching bases in these three areas is not sufficient. The benefits are at a low level. The main reasons are: (1) The orientation of the practice teaching base in the university is inaccurate, and the practice teaching base is completely equivalent to the practice base, resulting in the practice teaching base for local colleges only for graduation practice, apprenticeship, and graduation thesis. (Design) and other practical aspects, the role of employment in promoting the transformation of scientific research achievements and cultivating innovative talents is directly ignored. (2) There is no evaluation mechanism for the construction of practical teaching bases, because there is no scientific, fair and objective teaching base. The evaluation index system, colleges and universities in the selection of practice base, there is a certain amount of blindness, and there is a gap between the objectives of application-oriented personnel training. (3) Poor school-enterprise sharing and interoperability mechanisms resulted in the lack of research and discussion between the university and the company on the fields of cooperation and the development direction of the practice base, so that the two sides could use resources such as production technology, equipment resources, engineering experience, scientific research achievements and technical personnel. The advantages cannot be fully utilized, which restricts the comprehensive benefits of the practical teaching base. 


\section{Countermeasures for the Construction of Practical Teaching Bases in Local Colleges and Universities}

Based on the problems and deficiencies in the construction of practical teaching bases, local colleges should continue to improve the construction of practical teaching bases through the following strategies.

\subsection{Construct a long-term mechanism for school-enterprise cooperation}

The establishment of a long-term mechanism for school-enterprise cooperation is the basis for the sound development of the "practical education base." Schools should insist on in-depth cooperation with industry and enterprises and collaborative innovation, and continuously deepen the cooperation between schools and enterprises; further invest technical force, build innovative platforms with companies, and carry out scientific research in bases, design and development, technology promotion, marketing training, etc. Work, speed up the transformation of scientific research achievements, service enterprise transformation and upgrading. On this basis, the construction of practical education bases will be promoted so that the construction and operation of practical education bases will be effective in the cooperation between production, education and research and the long-term mechanism for school-enterprise cooperation.

\subsection{Improve the base of practical education management model}

First, rationalize and standardize the management institutions of the bases and set up a "practical education base construction committee" composed of schools, industry associations, and relevant leaders and experts of the enterprises. They are mainly responsible for the development planning, policy formulation, funding input, and platform construction of practical education bases. Wait for work. And establish a "Practical Education Center" suitable for the "enterprise operation" model, with the "Practical Education Center" leading and overall planning mode of operation. The "Practical Education Center" is specifically responsible for the service of the base, the organization and management of practical education, and the implementation and evaluation of the project. The membership of the "Practical Education Center" is determined by both parties. Second, strengthen the management of "practical education centers" and "practical projects". The "Practice Education Center" has clear rights and responsibilities and management practices. Under the leadership of the "Practice Education Base Construction Committee", the "Practice Education Center" will organize the project planning and design practice projects for both schools and enterprises, and strengthen the management of the "Practice Project" implementation.

\subsection{Standardize teaching planning and system management}

First of all, in order to better exert the function of the base and the effectiveness of the compound application-type talent cultivation, the school and the enterprise should strengthen cooperation and educate talents together. The talent demand in the industrial cluster should be included in the talent training program. Schools and enterprises should work out a talent training plan together. Prepare and revise the syllabus and practice syllabus, prepare and revise the teaching plan for practical teaching, compile and improve the task book of practical teaching project, and prepare instructional teaching materials that meet the characteristics of the students, so as to cultivate composite applied talents meeting the needs of the industry. . Secondly, perfecting the practice education management system and standardizing the teaching management are the preconditions for guaranteeing the practical education effect of college students. Constantly improve the rules and regulations of the practice education base and establish a set of effective practice education base management methods to make the base management work standardized, standardized, and scientific. For example, improve the "Practice Management Measures", "Students' Practice Regulations outside School Practice Teaching Safety Management", "Practice Education Staff Job Responsibility", "Practice Teaching Management Measures", "Practice Education Student Code", "Practice Education Base Construction and Management" "Systems and Measures" and other institutionalized documents, and the establishment of a filing 
management system for practical education documents, the implementation of the implementation of practical education management methods, to ensure the protection of practical education for college students.

\subsection{Improve the "double teachers" quality of teachers}

A high-level practical teaching team is a necessary condition for practical education bases to perform their functions, and it is a direct guarantee for improving practical education guidance levels and rapidly improving students' practical ability. For schools, the combination of training and introduction, high education, and high skills should be used to formulate a professional and comprehensive teacher team building plan that combines the qualities of "dual divisions" and "dual divisions". Various forms of professional teacher practical skills training have been carried out to improve teachers' practical education and instructional capabilities in various forms.

\section{Conclusion}

The construction level of practical teaching bases for local colleges and universities in the context of the transformation and upgrading of industrial clusters profoundly reflects the degree of integration of production and education in universities and the strength of school-enterprise cooperation. In the construction of the base, deepen and refine cooperative education of production, education and research, and interact with colleges and universities to cultivate talent models. Utilizing different educational environments of universities and enterprises to develop two kinds of educational resources can provide effective training for applied talents, local economy, and stand by development of universities

\section{References}

[1] Wang Sunqi, Zhao Ziqiang, Lei Huan. National Innovation Road and New Progress in Higher Engineering Education Reform [J]. Research in Higher Engineering Education, 2013, (1): 14-22.

[2] Guo Qibin, Fan Wenbin, Wang Huaidong et al. Building a Sustainable Development Vocational Teaching Base for Higher Vocational Education [J]. China Higher Education, 2010 (23): 53-54

[3] Zhang Guohui. Research on the Construction of School-Enterprise Cooperative Practice Teaching Base: Based on Application-oriented Universities [J]. Financial Teaching and Research, 2015(3):77-80

[4] Hui Jizhuang, Zhang Lei, Sun Deshi. Exploration of practice teaching base construction and management evaluation index [J]. Experimental Technology and Management, 2009, 26(10): 11-14

[5] Yi Honglei, Xue Yuan, Zhang Caiyun, et al. Off-campus Practice Base Construction Based on School-Enterprise Cooperative Alliance Model [J]. Experimental Technology and Management, 2011, 28(4): 139-142 